\title{
Histological evaluation of the intestine of broiler chickens: comparison of three sampling methods
}

\section{Avaliação histológica do intestino de frangos de corte: comparação de três métodos de colheita}

\author{
Marielen de Souza ${ }^{1 *}$; Claudineia Emidio Cicero2; Maísa Fabiana Menck-Costa3; \\ Larissa Justino4; Juliana Rubira Gerez; Ana Angelita Sampaio Baptista6; \\ Ana Paula Frederico Rodrigues Loureiro Bracarense ${ }^{7}$
}

\section{Highlights}

Intestinal health is a key factor to achieve optimal zootechnical performance.

Few studies evaluated sampling methods for histological evaluation.

Histology is a traditional and cheap technic for intestinal health evaluation.

Swiss roll method best preserved the intestinal morphology of broilers.

\begin{abstract}
After the growth-promoting antibiotics prohibition, intestinal health became an increasing concern worldwide in poultry farming. The intestinal histological evaluation is an inexpensive technique that brings relevant information, but in poultry, the immediate process of intestinal post-mortem autolysis interferes directly on the samples quality for histological analysis hindering a precise diagnosis. This study aimed to standardize a technique for broilers' intestines sample collection and fixation for histological analysis. Seven broiler chickens received a standard diet until 23 days of age when they were euthanized. Fragments of duodenum, jejunum, and ileum were collected using three methods: intestine strips, transverse section, and Swiss roll and posteriorly fixed in $10 \%$ buffered formalin and bouin solution. Tissue samples were submitted for histological (number of villi and viable villi per field) and morphometrical (villi height, crypt depth and villi:crypt ratio) evaluations and the results analyzed statistically. A significant high number of villi and viable villi per field in all regions was observed in the Swiss roll method. In the duodenum $(p=0.0066)$

1 Doctorate Student in Animal Science, Universidade Estadual de Londrina, UEL, Londrina, PR, Brazil. E-mail: marielen. souza@uel.br

2 Graduating Student of Veterinary Medicine, UEL, Londrina, PR, Brazil. E-mail: claudineia.emidio@uel.br

3 Doctorate Student in Microbiology, UEL, Londrina, PR, Brazil. E-mail: maisa.menckcosta@uel.br

${ }^{4}$ Master Student, in Veterinary Sciences, Universidade Estadual Paulista Júlio de Mesquita Filho, UNESP, Botucatu, SP, Brazil. E-mail: larissajustino7@hotmail.com

5 Profa Dra ${ }^{a}$ at Histology Departament, UEL, Londrina, PR, Brazil. E-mail: julianarubira@uel.br

${ }^{6}$ Profa Dra ${ }^{a}$ at Department of Preventive Veterinary Medicine, DPVM, UEL, Londrina, PR, Brazil. E-mail: anaangelita@ uel.br

7 Profa Dra, at DPVM, UEL, Londrina, PR, Brazil. E-mail: anapaula@uel.br

* Author for correspondence
\end{abstract}

Received: Nov. 08, 2020 - Approved: July 04, 2021 
and jejunum ( $p=0.0058)$ an interaction between the Swiss roll method and the fixative buffered formalin was observed in the viable and number of villi per field, respectively. Regarding the morphometrical analysis significant differences were observed, in the jejunum villi height sampling by the methods Swiss roll $(1,157.66 \pm 148.25 \mu \mathrm{m}, \mathrm{p}=0.0015)$ that showed the highest mean. Deeper crypt depths were observed in the jejunum $(156.59 \pm 15.68 \mu \mathrm{m}, \mathrm{p}=0.0002)$ and ileum $(131.13 \pm 15.01 \mu \mathrm{m}, \mathrm{p}=0.0006)$ collect by the Swiss roll method. An interaction between the bouin fixative was also observed in the jejunum $(p=0.0223)$ for this variable. Duodenum sampling by transversal section $(12.68 \pm 1.45 \mu \mathrm{m}, \mathrm{p}=0.0076)$ was the only segment that had a significant difference for villi:crypt ratio, showing the highest mean. It can be concluded that the Swiss roll technique was the best method for morphometrical evaluation of the chickens' intestines, since the highest counts of villi per field and viable villi per field were obtained, while buffered formalin was considered as the best fixative.

Key words: Post-mortem autolysis. Histology. Intestinal health. Intestinal morphometry. Poultry.

\section{Resumo}

Após a proibição da utilização dos antimicrobianos promotores de crescimento, saúde intestinal se tornou uma preocupação crescente na avicultura mundialmente. A avaliação histológica intestinal é uma técnica de baixo custo que traz informações relevantes, porém nas aves, o imediato processo de autólise intestinal post-mortem interfere diretamente na qualidade da amostra para histologia dificultando um diagnóstico preciso. Este estudo objetivou a padronização de uma técnica para coleta e fixação do intestino de frangos de corte para análise histológica. Sete frangos de corte receberam uma dieta padrão até 23 dias de vida, quand o foram eutanasiados. Fragmentos de duodeno, jejuno e íleo foram coletados utilizando três métodos: intestino aberto, corte transversal e rocambole, e posteriormente fixados em formalina tamponada $10 \%$ e solução de bouin. Amostras de tecidos foram submetidas a avaliações histológicas (número de vilosidades e vilosidades viáveis por campo) e morfométricas (altura de vilosidade, profundidade de cripta e relação vilosidade:cripta) e os resultados analisados estatisticamente. Um significativo maior número de vilosidades e vilosidades viáveis por campo foi observado, em todos os segmentos intestinais, no método rocambole. No duodeno $(p=0,0066)$ e jejuno $(p=0,0058)$ uma interação entre o método rocambole e o fixador formalina tamponada foi observado para as variáveis vilosidades viáveis e número de vilosidades por campo, respectivamente. Referente a análise morfométrica diferenças significativas foram observadas na altura de vilosidade no jejuno amostrado pelo método rocambole $(1.157,66 \pm 148,25 \mu \mathrm{m}, \mathrm{p}=0,0015)$ que apresentou a maior média. Criptas mais profundas foram observadas no jejuno $(156,59 \pm 15,68 \mu \mathrm{m}$, $p=0,0002)$ e íleo $(131,13 \pm 15,01 \mu \mathrm{m}, \mathrm{p}=0,0006)$ coletados pelo método rocambole. Uma interação entre o fixador bouin também foi observado no jejuno $(p=0,0223)$ para esta variável. Amostragem do duodeno pelo método corte transversal $(12,68 \pm 1,45 \mu \mathrm{m}, \mathrm{p}=0,0076)$ foi o único segmento que teve uma diferença significativa para relação vilosidade:cripta apresentando a maior média. Pode-se concluir que o método rocambole foi o melhor para avaliação morfométrica do intestino de frangos de corte, uma vez que as maiores contagens de vilosidades e vilosidades viáveis por campo foram obtidas, enquanto formalina tamponada foi considerada o melhor fixador.

Palavras-chave: Autólise post-mortem. Histologia. Saúde intestinal. Morfometria intestinal. Aves. 


\section{Introduction}

The gastrointestinal tract (GIT) is responsible for the digestive functions, and also for immunological and endocrinological roles (Oviedo-Rondón, 2019). Anatomically the small intestine of birds is divided into three parts duodenum, jejunum, and ileum, and its main function is the absorption of nutrients, electrolytes, and water (Ito, Miyaji; Myaji, \& Lima, 2009).

In the current animal production system a healthy intestine is required to achieve the best performance results, and the concept of intestinal health can be summarized as a state of intestinal homeostasis (Kogut, Yin; Yuan, \& Broom, 2017). The technological advances in the intensive animal production, the sanitary challenges and its increases after the prohibition of the use of growth promoters antibiotics in animal feed, due to the elevate bacterial resistance rates, made the topic intestinal health more relevant in the world poultry farming (Morgan, 2017; OviedoRondón, 2019).

Morphometric and morphological evaluations of the intestine using the light microscopy are simple and inexpensive methodologies widely used in intestinal health and performance evaluations (Belote et al. 2018; Suresh et al., 2020; Swatson, Gous, lji, \& Zarrinkalam, 2002). In birds, post mortem autolysis occurs extremely fast, starting at the intestine of broilers within 5-10 minutes (Smyth, 2016). Changes such as epithelial cell loss and lamina propria detachment are observed in this process that starts from the tip of the villus and later in the crypt making diagnosis difficult due to the complexity in differentiating autolysis from mild lesions (Fletcher \& Tahseen, 2016). This fast process observed in birds makes it a challenge to obtain high-quality histological sections.

Despite the significant technological advances, many sanitary challenges leads to economic losses to poultry production, especially those affecting the gastrointestinal tract (Oviedo-Rondón, 2019), and the histological evaluation of the intestines is often crucial in the diagnosis of these diseases. In necrotic enteritis disease, a severe broilers' intestinal infection caused by Clostridium perfringens, histological analyses are commonly performed to establish diagnosis. However, the differentiation of necrotic enteritis lesions from autolysis is challenging in some cases (Smyth, 2016).

There are numerous studies in rodents to evaluate different sampling methods (Bialkowska; Ghaleb, Nandan, \& Yang, 2016; Moolenbeek \& Ruitenberg, 1981; Silva, Lourenço, Marmello, Bitteti, \& Teixeira, 2019; Williams, Duckworth, Vowell, Burkitt, \& Pritchard, 2016). However, similar evaluations in broilers are scarce; to the best of the authors' knowledge this is the first study to evaluate the intestine of broilers with the Swiss roll sampling technique. Considering that post-mortem autolysis begins early in broilers, and that good quality samples are necessary to achieve a precise diagnosis, this study aimed to standardize a sampling technique that better preserves the integrity of the intestinal tissue. 


\section{Material and Methods}

\section{Animals and sample collection forms}

The experiment was approved by the Institutional Ethics Committee for Animal Experimentation under the protocol number: 12433.2018.03.

One day old broilers chickens $(n=7)$ were housed in experimental cages. Water and feed was provided ad libitum and heating according to the lineage guideline (Aviagen, 2018). At 22 days of age (DA) the animals were euthanized by cervical dislocation. Between the euthanasia and intestinal sampling no more than 15 minutes were spent to avoid changes due to post-mortem autolysis. The samples were collected using three methods: i. intestine strips: an intestinal fragment $(2 \mathrm{~cm})$ was opened by the mesenteric border; the ends were fixed in a polystyrene plate using stainless steel pins; ii. transverse section: an intestinal fragment $(2 \mathrm{~cm})$ was removed; iii. Swiss roll (Figure 1): an intestinal fragment (9 $\mathrm{cm}$ ) was opened by the mesenteric border, feces were carefully removed, after which the intestinal mucosa was washed with cold PBS solution, and a wooden stick $(4 \mathrm{~mm} \varnothing)$ was placed under the intestinal serosa and rolled as described (adapted from Moolenbeek and Ruitenberg (1981)). After samplings, the intestinal fragments were fixed in $10 \%$ buffer formalin or bouin solutions.

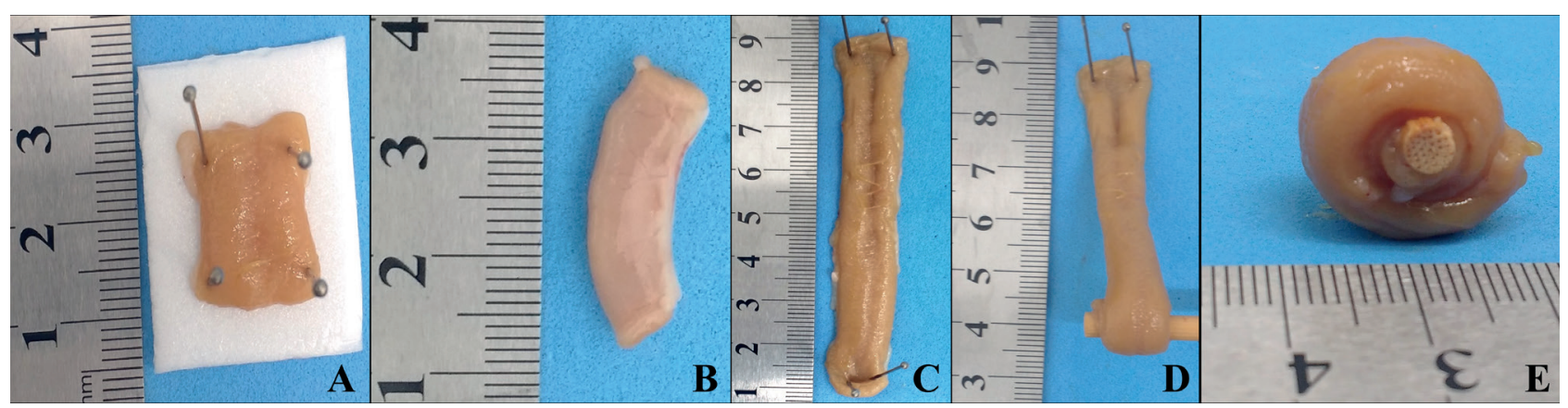

Figure 1. Sampling methods of broilers chickens' intestines at 22 days of age. Jejunum. A- intestine strips sampling method; B- transverse section sampling method; C, D, E Swiss roll sampling method.

\section{Intestinal morphometry and histological} analysis

After fixation for $24 \mathrm{~h}$, the fragments were cleaved, dehydrated in increasing alcohol concentrations and embedded in paraffin for histological analysis. Each sample of the duodenum, jejunum, and ileum were sectioned to $5 \mu \mathrm{m}$ thickness parallel to the villi axis, stained with hematoxylin and eosin (HE). For the morphometrical analysis (villi height, crypt depth and villi crypt:ratio) thirty villi and crypts were measured per animal at the duodenum (2.5X magnification for villi; $10 \mathrm{X}$ for crypt), jejunum and ileum (10X magnification). Histological analysis was used to evaluate the number of villi per field and to characterize the number of viable villi per field. 
Viable villi were characterized by straight villi clearly embedded in the submucosa, lined by columnar enterocytes and with no lamina propria detachment. Ten random fields were analyzed at the duodenum(2.5Xmagnification), jejunum and ileum (10X magnification). The Motic Image Plus 2.0 software (Motic Instruments, Richmond, Canada) was used for morphometrical assessment.

\section{Statistical analysis}

The experimental design was the factorial $3 \times 2$. The means from the measurements were submitted to the two-way ANOVA and later to Tukey multiple comparison test at significance level of $5 \%$.

\section{Results and Discussion}

The gastrointestinal tract has the important function of absorbing nutrients, and is also the largest exposed body surface, acting as a barrier against toxins and pathogens ingested by the animal (Yegani \& Korver, 2008). After the European Union's prohibition on the use of growthpromoting antibiotics in commercial poultry farming, intestinal diseases developed into an increasing challenge (Immerseel, Rood, Moore, \& Titball, 2009). In this context, the histological evaluation of the intestine has become an important tool for intestinal health evaluation.
Birds have a fast post-mortem intestinal autolysis process (Fletcher \& Tahseen, 2016; Smyth, 2016). One of the motivations to execute this study was the difficulty of our research group in obtaining a high-quality material for an accurate histological analysis. We believe that our results will contribute to the works of researchers that are involved in the intestinal histological evaluations of broilers. There are several studies comparing different forms of intestinal tissue sampling for histological evaluation in rodents (Silva et al., 2019; Williams et al., 2016), with comparatively few data for broilers.

Morphometrical measurement is an important tool for the evaluation of intestinal health since villi height is correlated with the intestinal absorption area and cryptal depths are correlated with the intestinal renewal rate (Swatson et al., 2002; Yamauchi, 2007; Qi et al., 2020), and is an essential step widely used during zootechnical performance trials (Biasato et al., 2018; Boroojeni; Manner; Rieger; Calvo, \& Zentek, 2019; Suresh et al., 2020).

The results of the intestinal morphometry for all regions are shown on Table 1. Relative to the villi height, jejunum collected by the Swiss roll technique $(p=0.0015)$ had the highest mean $(1,157.66 \pm 148.25 \mu \mathrm{m})$. The best results of crypt depth were observed at the jejunum $(p=0.0002,156.59 \pm 15.68 \mu \mathrm{m})$ and ileum $(p=0.0006,131.13 \pm 15.01 \mu \mathrm{m})$ collected by the Swiss roll technique. 


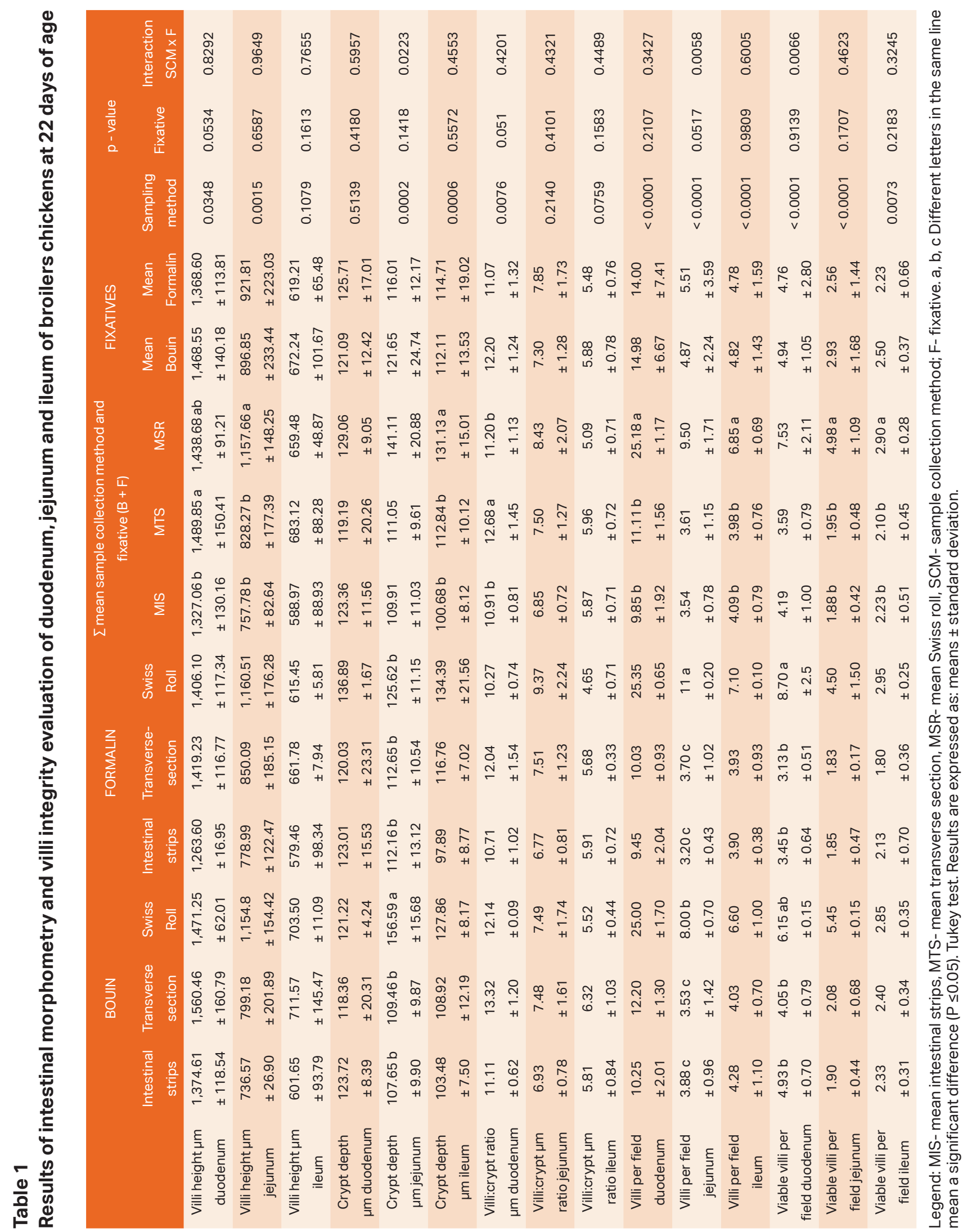


Swiss roll method showed the best morphometrical results, mainly at the jejunum; these findings are in accordance with those of Gava et al. (2015) that described the jejunum as the best region for morphometric analyses in the intestines of broilers.

When the morphometrical analysis was compared an interaction between the fixative and sampling method was observed only at the jejunum crypt depth $(p=0.0223)$, the best was attained with Swiss roll sampling fixed with bouin solution.

In the present study, the Swiss roll sampling method showed the highest number of villi ( $\cong 2.5$ fold in duodenum and jejunum, $\cong 1.6$ fold in ileum) and viable villi per field $(\cong 1.7$ fold at duodenum; $\cong 2.6$ fold in jejunum, $\cong 1.3$ fold in ileum) in all intestinal regions evaluated when compared with collections done using the intestinal strips and transverse section methods (Figure 2, 3). Similar findings were reported in previous studies in mice that evaluated only Swiss roll (Bialkowska et al., 2016) and gut bundling (similar to the transverse section applied on this research) and Swiss roll (Williams et al., 2016). Bialkowska et al. (2016) and Williams et al. (2016) have considered that the Swiss roll method allows the evaluation of a large tissue section, this fact can be associated with the best results found in this study. A higher number of villi and viable villi per field will facilite histological evaluations such as: goblet cells and intraepithelial lymphocytes count, and lesion score evaluations. On the other hand, in a study using intestinal broilers' section, the hemicylindrical sectional method was considered the best, but the Swiss roll methodology was not evaluated (Gava et al., 2015). In addition, in rodents, intestinal strips were considered most suitable for wider histological evaluation (Silva et al., 2019), while the gut bundling method was considered better for villi and crypt measurements (Williams et al., 2016). To the best of the authors' knowledge, this is the first evaluation of Swiss roll sampling method in broilers' intestine.

A significant histological feature within the normal parameters with few artifacts was observed in all intestinal tissues sampled by the Swiss roll technique (Figure 4). In these sections, well-delineated and straight villi were observed, whereas the intestinal sections collected by other methods were folded, and broken villi were commonly observed (Figure $4 A, B)$. In addition, a high number of villi per field was noticed in the Swiss roll sampling method when compared to the other techniques (Figure 4C). 


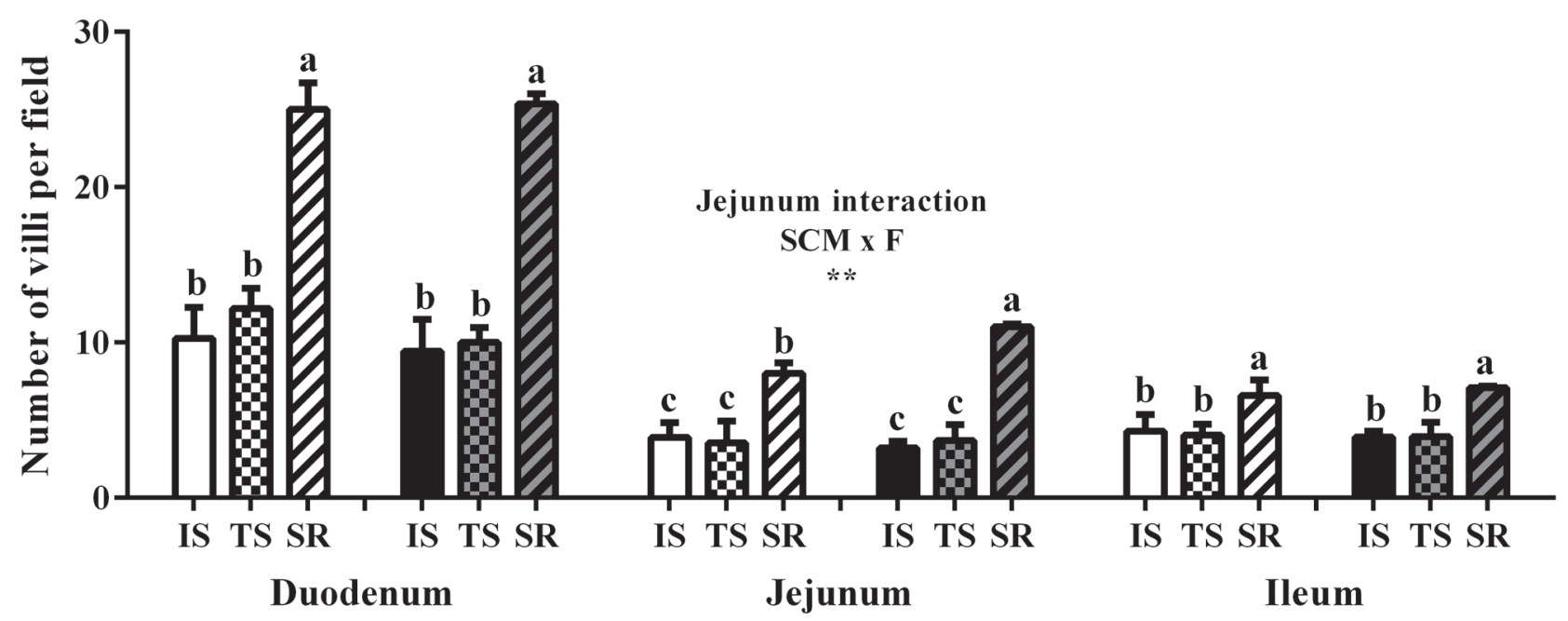

Figure 2. Comparative number of villi per field in duodenum, jejunum and ileum by three different sampling methods (intestine strips, transverse section and Swiss roll) and fixed in two types of fixatives (bouin and buffered formalin).

Duodenum, jejunum and ileum. SCM (sample collection method), F (fixative). IS- intestine strips SCM fixed with bouin ( $\square$ ); TS- transverse section SCM fixed with bouin ( $\mathbf{Q}$ ); SR- Swiss roll SCM fixed with bouin ( $\square$ ). IS- intestine strips SCM fixed with buffered formalin ( $\mathbf{0}$ ); TS- transverse section SCM fixed with buffered formalin ( $\mathbf{B}$ ); SR- Swiss roll SCM fixed with buffered formalin $(\boldsymbol{G})$. $a, b, c$ Different letters are significantly different $(P \leq 0.05)$. Tukey test. Means \pm standard deviation.

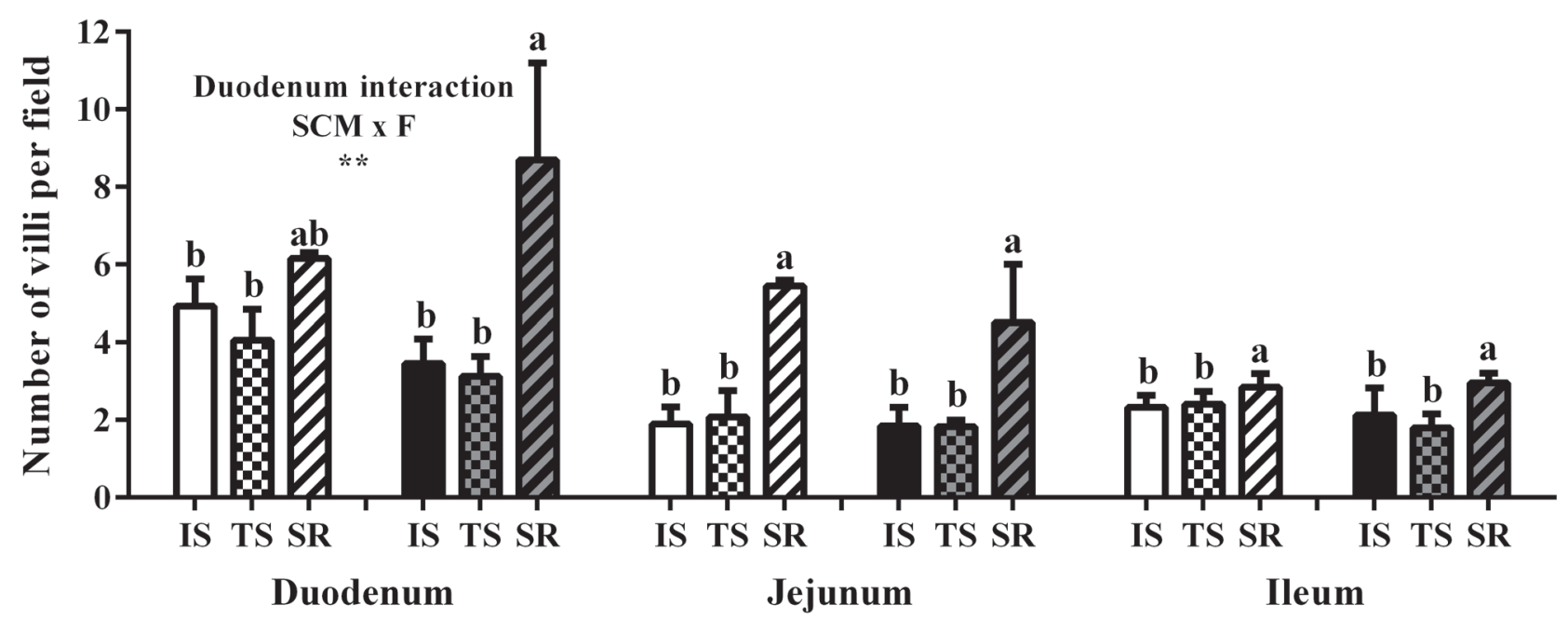

Figure 3. Comparative number of viable villi per field in duodenum, jejunum and ileum sampled by three different methods (intestine strips, transverse section and swiss roll) and fixed in two types of fixatives (bouin and buffered formalin).

Duodenum, jejunum and ileum. SCM (sample collection method), F (fixative). IS- intestine strips SCM fixed with bouin ( $\square$ ); TS- transverse section SCM fixed with bouin ( $\mathbf{Q}$ ); SR- Swiss roll SCM fixed with bouin $(\square)$. IS- intestine strips SCM fixed with buffered formalin ( $\square$ ); TS- transverse section SCM fixed with buffered formalin ( $\mathbf{B})$; SR- Swiss roll SCM fixed with buffered formalin ( $\boldsymbol{Z}$ ). $a, b, c$ Different letters are significantly different $(P \leq 0.05)$. Tukey test. Means \pm standard deviation. 


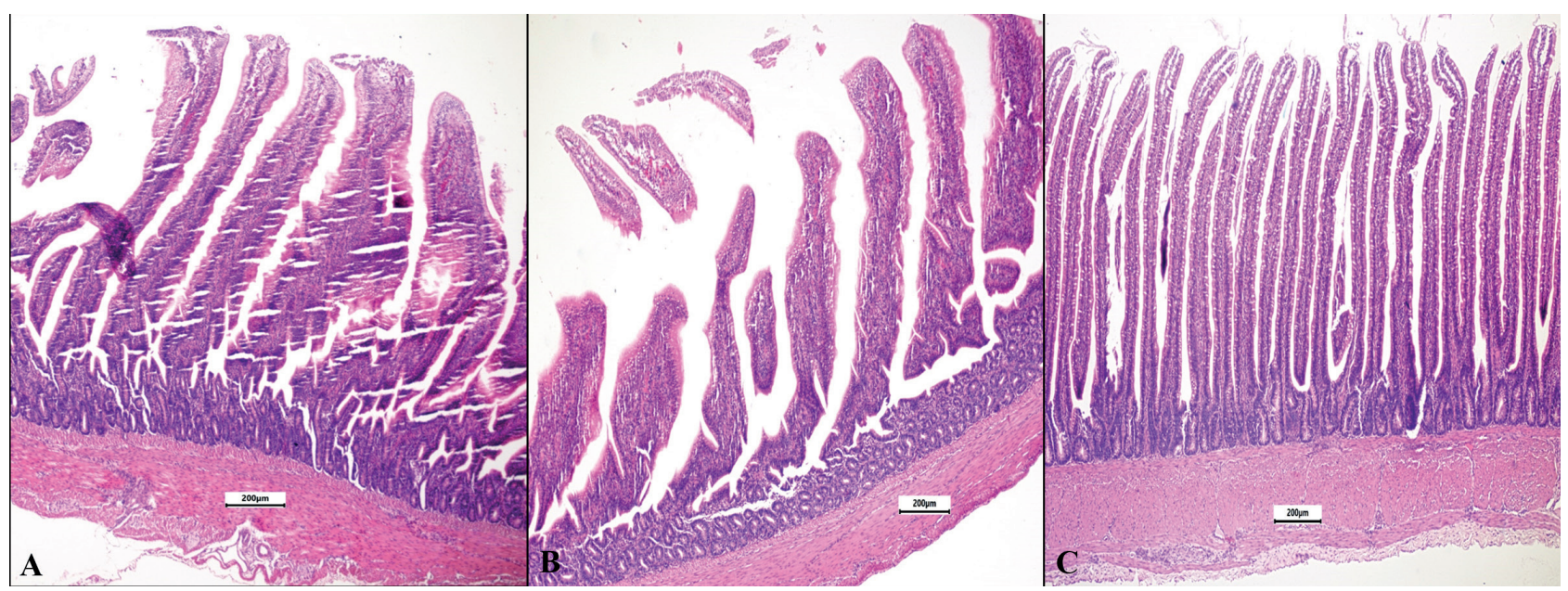

Figure 4. Photomicrography of jejunum of broilers chickens with 22 days of age sampled by different methods and fixed with $10 \%$ buffered formalin solution.

A- Intestine strips method. The villi apical region is folded, and some villi are broken. HE. Bar 200 $\mu \mathrm{m} ; \mathrm{B}$ - Transverse section method. Villi showing folds and breaks, interfering with morphometrical analysis. HE. Bar $200 \mu \mathrm{m}$; C- Swiss roll method. Villi showing a straight position. A high number of villi is observed in the field. HE. Bar $200 \mu \mathrm{m}$.

The overlapping of tissue layers in the Swiss roll method can be a reason of the best results, preserving the morphology of the intestinal villi, once even the mucus layer is conserved. There are two principal challenges in the utilization of Swiss roll method: it's laborious and training is needed. When the executant is not well trained a common artifact found on the Swiss roll slides is the villi distorting in the inner layers, as consequence of the excessive pressure during the rolling process, but same with this artifact the slides evaluator will still have a large amount of tissue to examine from the outer layers. Although the advantages this method needs training and experience for a correct execution.

Concerning the fixatives, a significant difference was observed only for the variables that showed interaction (fixative and sampling method). Jejunum $(p=0.0058)$ villi per field, and duodenum ( $p=0.0066)$ viable villi per field, were higher when fixed with buffered formalin. Bouin fixative was considered as the best to observe and analyze the crypt depth at the jejunum ( $p=0.0223$ ).

Formalinisconsideredforsomeauthors as the "universal" fixative (Buesa, 2008; Jones, 2007; Patil, Premalatha, Rao, \& Ganavi, 2013; Rajanikanth, Ravi, Sreenath, Sonia, \& Shyam, 2015). Besides the best results found in this study, some of its use advantages are: a rapid penetration on the tissue, a good preservation of proteins, a good preservation of lipids, most commercial antibody manufactured for immunohistochemistry techniques optimized their products for formalin-fixed tissues, it is readily available, cheap, fairly convenient to store, allows long-term storage, and it is very safe to use when the security protocols are followed (Buesa, 2008). Another advantage 
of this fixative is the good results when the DNA extraction from formalin-fixed tissues are performed, the same does not occur when bouin fixative is used (Santos, Saito, \& Line, 2008).

\section{Conclusions}

The results of this study have shown that the Swiss roll method was the best technique for morphometrical evaluation of the chickens' intestines, since the highest counts of villi per field and viable villi per field were obtained; in relation to the fixatives the buffered formalin showed the best results.

\section{Acknowledgments}

The authors would like to acknowledment to the post-graduation program in Animal Science (UEL) and the Conselho Nacional de Desenvolvimento Científico e Tecnológico (CNPq) for the scholarship granted to Marielen de Souza.

\section{References}

Aviagen. (2018). Ross manual de manejo de frangos de corte. 2018.

Belote, B. L., Tujimoto-Silva, A., Hümmelgen, P. H., Sanches, A. W. D., Wammes, J. C. S., Hayashi, R. M., \& Santin, E. (2018). Histological parameters to evaluate intestinal health on broilers challenged with Eimeria and Clostridium perfringens with or without enramycin as growth promoter. Poultry Science, 97(7), 22872294. doi: $10.3382 /$ ps/pey064
Bialkowska, A. B., Ghaleb, A. M., Nandan, M. O., \& Yang, V. W. (2016). Improved swissrolling technique for intestinal tissue preparation for immunohistochemical and immunofluorescent analyses. Journal of Visualized Experiments, 13(113), 1-8. doi: $10.3791 / 54161$

Biasato, I., Gasco, L., Marco, M., Renna, M., Rotolo, L., Dabbou, S.,... Schiavone, A. (2018). Yellow mealworm larvae (Tenebrio molitor) inclusion in diets for male broiler chickens: effects on growth performance, gut morphology, and histological findings. Poultry Science, 97(2), 540-548. doi: 10. 3382/ps/pex308

Boroojeni, F. G., Männer, K., Rieger, J., Calvo, E. P., \& Zentek, J. (2019). Evaluation of a microbial muramidase supplementation on growth performance, apparent ileal digestibility, and intestinal histology of broiler chickens. Poultry Science, 98(5), 2080-2086. doi: 10.3382/ps/pey556

Buesa, R. J. (2008). Histology without formalin? Annals of Diagnostic Pathology, 12(6), 387-396. doi: 10. 1016/j. anndiagpath.2008.07.004

Fletcher, O. J., \& Tahseen, A.-A. (2016). Alimentary system. In T. Abdul-Aziz, O. J. Fletcher, \& H. J. Barnes (Eds.), Avian histopathology (4nd ed., pp. 271-354). Jacksonville: American Association of Avian Pathologists.

Gava, M., Moraes, L., Carvalho, D., Chitolina, G., Fallavena, L., Moraes, H.,... Salle, C. (2015). Determining the best sectioning method and intestinal segment for morphometric analysis in broilers. Brazilian Journal of Poultry Science, 17(2), 145-149. doi: 10. 1590/1516-635x1702145-150 
Immerseel, F. V., Rood, J. I., Moore, R. J., \& Titball, R. W. (2009). Rethinking our understanding of the pathogenesis of necrotic enteritis in chickens. Trends Microbiology, 17(1), 32-36. doi: 10.1016/j.tim.2008.09.005

Ito, N. M. K., Miyaji, C. I., Myaji, S. O., \& Lima, E. A. (2009). Fisiopatologia do sistema digestório e anexos. In A. Berchieri, Jr., E. N. Silva, J. D. Fabio, J. D. Fabio, L. Sesti, \& M. A. F. Zuanaze (Eds.), Doenças das aves (2a ed., pp. 215-256). Campinas: Facta.

Jones, M. L. (2007). How formalin affects the outcome of routine and special stains. Biotechnic \& Histochemistry, 82(3), 155159. doi: $10.1080 / 10520290701567908$

Kogut, M. H.; Yin, X.; Yuan, J. \& Broom, L. (2017). Gut health in poultry. Perspectives in Agriculture, Veterinary Science, Nutrition and Natural Resources, 12(31), 1-7. doi: $\quad$ 10.1079/PAVSNNR201712031 Recovered from https://www.cabdirect. org/cabdirect/abstract/20173301742

Moolenbeek, C., \& Ruitenberg, E. J. (1981). The "Swiss roll": a simple technique for histological studies of the rodent intestine. Laboratoy Animals, 15(1), 5759. doi: $10.1258 / 002367781780958577$

Morgan, N. K. (2017). Managing gut health without reliance on antimicrobials in poultry. Animal Production Science, 57(11), 2270-2279. doi: 10.1071/AN17288

Oviedo-Rondón, E. O. (2019). Holistic view of intestinal health in poultry. Animal Feed Science and Technology, 250(2019), 1-8. doi: 10.1016/j.anifeedsci.2019.01.009

Patil, S., Premalatha, B. R., Rao, R. S., \& Ganavi, B. S. (2013). Revelation in the field of tissue preservation - a preliminary study on natural formalin substitutes. Journal of International Oral Health, 5(1), 31-38.

Qi, D., Shi, W., Black, A. R., Kuss, M. A., Pang, X., He, Y.,... Duan, B. (2020). Repair and regeneration of small intestine: $A$ review of current engineering approaches. Biomaterials, 240(2020), 119832. doi: 10. 1016/j.biomaterials.2020.119832

Rajanikanth, M., Ravi, P. A., Sreenath, G., Sonia, B. J. K., \& Shyam, N. D. V. N. (2015). Transit fixatives: an innovative study. Journal of Clinical and Diagnostic Research, 9(3), 1-3. doi: 10.7860/JCDR/2015/11083.5615

Santos, M. C. L. G., Saito, C. P. B., \& Line, S. R. P. (2008). Extraction of genomic DNA from paraffin-embedded tissue sections of human fetuses fixed and stored in formalin for long periods. Pathology Research and Practice, 204(9), 633-636. doi: 10.1016/j.prp.2008.04.005

Silva, A.P., Lourenço, A. L., Marmello, B. O., Bitteti, M., \& Teixeira, G. A.P. B. (2019). Comparison of two techniques for a comprehensive gut histopathological analysis: Swiss Roll versus Intestine Strips. Experimental and Molecular Pathology, 111(2019), 104302. doi: 10.1016/j.yexmp.2019.104302

Smyth, J. A. (2016). Pathology and diagnosis of necrotic enteritis: is it clear-cut? Avian Pathology, 45(3), 282-287. doi: 10.1080/03079457.2016.1158780

Suresh, G., Santos, D. U., Rouissi, T., Hegde, K., Brar, S. K., Mehdi, Y.,... Ramirez, A. A. (2020). In-field poultry tests to evaluate efficacy of bioformulation consisting of enzymes and yeast biomass. Animal Feed Science and Technology, 262(2020), 114398. doi: 10.1016/j.anifeedsci.2020.114398 
Swatson, H. K., Gous, R., lji, P. A., \& Zarrinkalam, R. (2002). Effect of dietary protein level, amino acid balance and feeding level on growth, gastrointestinal tract, and mucosal structure of the small intestine in broiler chickens. Animal Research, 51(6), 501-515. doi: 10.1051/animres:2002038

Williams, J. M., Duckworth, C. A., Vowell, K., Burkitt, M. D., \& Pritchard, D. M. (2016). Intestinal preparation techniques for histological analysis in the mouse. Current Protocols in Mouse Biology, 6(2), 148-168. doi: $10.1002 / \mathrm{cpmo.2}$
Yamauchi, K. (2007). Review of a histological intestinal approach to assessing the intestinal function in chickens and pigs. Animal Science Journal, 78(4), 356-370. doi: 10.1111/j.1740-0929.2007.00448.x

Yegani, M., \& Korver, D. R. (2008). Factors affecting intestinal health in poultry. Poultry Science, 87(10), 2052-2063. doi: 10.3382/ps.2008-00091 